\title{
OPPORTUNITIES FOR RESTORATION OF SOIL FERTILITY THROUGH METHODS OF ORGANIC AGRICULTURE IN THE YAMBOL AGROREGION
}

\author{
Violeta Vateva \\ Faculty of Technics and Technologies, Trakia University, Bulgaria \\ Graf Ignatiev 38, 8600 Yambol, Bulgaria, e-mail: vili13@gmail.com
}

\begin{abstract}
The quality and quantity of agricultural production depend on the fertility of the soil type on which it is grown. Soil fertility is the result of the interaction of multiple mutually merged factors. Loss of soil fertility leads to soil degradation. Subsequently, it gradually becomes unfit for farming activity. Controlling the maintenance and enhancement of soil fertility is the guarantor of sustainable yields and population satisfaction with food resources, protecting land from degradation, and preserving biodiversity of ecosystems. The report examines the opportunities for restoration of the soil fertility of the agricultural lands of the Yambol Agro region. The aim is to analyze and propose for practice the most suitable methods of organic farming, with the application of which to preserve and improve the fertility of soils from the agricultural fund of the region. The proposed options are in line with the requirements of the European Union and the elements of the Common Agricultural Policy for Conservation of Soil Fertility. As a result of analysis and studies found that the preservation and maintenance of soil fertility in agricultural land in Yambol agro region is recognized and priority policy of the departments of Agriculture and farmers. From soil fertility conservation methods, organic farmers in Yambol Agro region apply a comprehensive approach, focusing primarily on bio-fertilization, crop rotation and sequential soil treatment systems.
\end{abstract}

Key words: soil fertility, soil degradation, soil restoration, organic agriculture, Yambol Agro region.

\section{INTRODUCTION}

From the commercialization of agriculture, and the growing chemistry in growing crops, the soil is most injurious. After long and uncontrolled use of agricultural land, the surface soil layer degrades and it loses its most valuable quality - fertility. Soils with low fertility are often abandoned. In order to regain their fertility, it is necessary to implement measures for its recovery.

The fertility of the soil is its ability to supply on plants throughout the growing season with sufficient amounts of digestible nutrients and water and thus determine the quantity, and quality of the agricultural production [7], [17]. In the report of the European commission for the period 2005-2015 concluded that it is necessary to ensure sustainable land use.

For purpose, further degradation of soils, preservation of their functions and restoration of degraded soils should be prevented [8]. This finding is largely valid for non-arable land.

In agricultural areas, especially those used in conventional farming, soil fertility is threatened, and for the most part the soil is with degraded surface treatment layer [3], [2], [5].

A plurality of complex coupled elements define the fertility of the soil as: humus horizon power, quantity and composition of humus, mechanical and mineralogical composition, absorption capacity and composition of the exchange bases, soil reaction, structural state, activity of soil microorganisms, etc.

The European Union's environmental measures [13] and the Strategy for Sustainable Development of Agriculture in Bulgaria for the period 2014-2020 [1] show concern about the conservation of soil fertility. Agricultural production in the Yambol Agro region plays a

IRTIIE Vol. 6, No. 4, 2018 ISSN 1314-8788 (print), ISSN 1314-8796 (online), doi: 10.15547/artte.2018.04.001 


\section{ARTTIE $Y$}

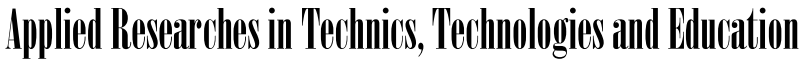

Journal of the Faculty of Technics and Technologies, Trakia University https://sites.google.com/a/trakia-uni.bg/artte/

significant role in the economy of the areal. This sector is an important source of income for a large part of the population. Part of the resulting agricultural output is used for the food industry in the region, including livestock feed.

The purpose of this article is to reflect the methods of soil fertility restoration in organic farming, and to give specific guidance to bio-producers in the Yambol region to implement these measures. In the article are applied results of a poll conducted with agricultural organic producers in Yambol Agro region.

\section{METHODS AND RESULTS}

Organic farming is, in its essence, an antipode of conventional agriculture and a real practice for preserving soil fertility [4], [6], [16]. The dependence between quality and quantity of agricultural production and organic farming is predetermined by the available potential fertility of each soil type [11], [12], [14]. Registered agricultural bio producers are subject to sanctions if they do not support the declared areas in good agricultural and environmental condition. In this respect, they are committed to protecting the soil from erosion, preserving its good structure and the organic matter in it. In the Yambol region, conventional agriculture occupies a large part of the agricultural land. In recent years, there has been a favorable trend towards increasing the number of organic producers. Total from 2010 to early 2016 organic growers registered are 135 [15]. According to the national statistics, organic producers in the Yambol region are only $2.8 \%$ of the total registered in Bulgaria. In the Organic farming has different methods of restoring and maintaining soil fertility (Table 1). Applied in combination, they actually guarantee the good condition of soil resources.

Table 1. Methods of recovery and maintenance of soil fertility in Organic farming

\begin{tabular}{|c|c|c|}
\hline Event & Rationale for the event & Maintains soil fertility by: \\
\hline $\begin{array}{l}\text { 1. Agro-climatic areas } \\
\text { 1.1. Macro-areas } \\
\text { 1.2. Micro-areas }\end{array}$ & $\begin{array}{l}\text { Proper distribution of species } \\
\text { and varieties of crops, } \\
\text { depending on the } \\
\text { combination of soil and } \\
\text { climatic } \\
\text { determined by geographic } \\
\text { location. }\end{array}$ & $\begin{array}{l}\text { Providing a range of external } \\
\text { conditions that are necessary } \\
\text { for the development of } \\
\text { agricultural crops and for the } \\
\text { formation of normal yield. }\end{array}$ \\
\hline 2. Soil treatment systems & $\begin{array}{l}\text { Proper and consistent series } \\
\text { of soil treatments in } \\
\text { accordance with specific soil } \\
\text { and climatic conditions and } \\
\text { within a crop rotation. }\end{array}$ & $\begin{array}{l}\text { Maintenance of the surface } \\
\text { soil layer in good structural } \\
\text { condition; improvement of } \\
\text { the physical and physical- } \\
\text { mechanical properties of the } \\
\text { soil; inclusion of the organic } \\
\text { substance in the biogenic } \\
\text { circle of the substances. }\end{array}$ \\
\hline 3. Crop rotation & $\begin{array}{l}\text { Every year, crops alternate } \\
\text { on the basis of their } \\
\text { biological and ecological } \\
\text { characteristics. }\end{array}$ & $\begin{array}{l}\text { Accumulation of organic } \\
\text { matter; preservation of the } \\
\text { structure of the soil; } \\
\text { improving the balance of } \\
\text { nutrients, particularly to } \\
\text { nitrogen by incorporating } \\
\text { legumes; soil protection from } \\
\text { erosion processes; } \\
\text { control on weeds, diseases } \\
\text { and pests. }\end{array}$ \\
\hline
\end{tabular}

IRTIIE Vol. 6, No. 4, 2018 ISSN 1314-8788 (print), ISSN 1314-8796 (online), doi: 10.15547/artte.2018.04.001 


\section{IRTTIE}

Ipplied Researl reses in Technics, Technologies and Bduration Journal of the Faculty of Technics and Technologies, Trakia University https://sites.google.com/a/trakia-uni.bg/artte/

4. Organic fertilization

4.1. Liquid and solid manure

4.2. Green manure

4.3. Composting with organic waste

4.4. Biological fertilizers
Increase of organic matter

and nutrients;

Improving the physical

properties of the soil, and soil structure.

The analysis of strengths and weaknesses, opportunities and threats (SWOT analysis) presents the characteristic factors affecting soil fertility in Organic Farming (table 2). The SWOT analysis, which is a more detailed and in-depth vision of the state of fertility in organic farming, complements bio-farmers' knowledge of adequate actions and counter-measures to preserve soil fertility. From the presented SWOT analysis it is evident that the wide range of opportunities for preserving and maintaining soil fertility in the Yambol region has good opportunities for its preservation.

Table 2. SWOT Analysis: "Soil Fertility in Organic Farming"

\begin{tabular}{|c|c|}
\hline Strengths & Weaknesses \\
\hline $\begin{array}{l}>\text { The number of certified organic growers is } \\
\text { growing. } \\
>\text { Bulgaria produce organic products that } \\
\text { are sought for export. } \\
>\text { Provides nutrients and all other necessary } \\
\text { conditions for plant growth, development } \\
\text { and productivity. } \\
>\text { The effectiveness of organic farming } \\
\text { depends primarily on soil fertility, which is } \\
\text { the basis of obtaining real yields from } \\
\text { agricultural crops. } \\
>\text { It uses organic farming methods that are } \\
\text { environmentally friendly and preserve and } \\
\text { preserve the soil and the environment. } \\
>\text { It uses organic farming methods that are } \\
\text { environmentally friendly and preserve and } \\
\text { preserve the soil and the environment. }\end{array}$ & $\begin{array}{l}>\text { There is no understanding by farmers } \\
\text { about the nature of organic farming. } \\
>\text { No interest of the farmers to implement the } \\
\text { scientific achievements in the field of organic } \\
\text { farming. } \\
>\text { Rapid loss of soil fertility due to } \\
\text { unreasonable use of farmland. } \\
>\text { Rapid loss of soil fertility due to erosion and } \\
\text { other degradation processes. } \\
>\text { Slow and labor-intensive recovery of soil } \\
\text { fertility. } \\
>\text { Uncontrolled and not rational utilization of } \\
\text { soil resources by farmers. } \\
>\text { No measures are being taken to conserve } \\
\text { and restore soil fertility. }\end{array}$ \\
\hline Opportunities & Threats \\
\hline $\begin{array}{l}>\text { Presence of natural resources for the } \\
\text { development of organic farming in Bulgaria } \\
\text { and the Yambol region. } \\
>\text { Growing demand for organic Bulgarian } \\
\text { products on the foreign market. } \\
>\text { Increasing the efficiency of organic } \\
\text { farming can be achieved by restoring and } \\
\text { maintaining soil fertility. } \\
>\text { Validation of appropriate measures to } \\
\text { restore and maintain soil fertility. } \\
>\text { Introduction of practical measures for } \\
\text { restoration and maintenance of soil fertility. }\end{array}$ & $\begin{array}{l}\text { > Increased competition from conventional } \\
\text { agriculture products. } \\
\text { > Reduced demand for organic products due } \\
\text { to their higher market price. } \\
\text { > Unreasonable use of farmland can lead to: } \\
\text { - permanent loss of soil fertility; } \\
\text { - deterioration of the soil structure; } \\
\text { - deterioration of the physical and physico- } \\
\text { mechanical properties of the soil; } \\
\text { - erosion, degradation and desertification of } \\
\text { much of the agricultural land; } \\
\text { - local loss of biodiversity; } \\
\text { - ecological crisis in a smaller or larger part of } \\
\text { different geographic regions. }\end{array}$ \\
\hline
\end{tabular}




\section{ARTTIE $Y$}

Ipplied Resseirl'hes in Teednicis, Technologies and Eductation

Journal of the Faculty of Technics and Technologies, Trakia University https://sites.google.com/a/trakia-uni.bg/artte/

In recent years, agriculture in Yambol region, including Organic Farming, faces challenges and threats of national and regional scale - demographic collapse, global competition from imports of agricultural products, negative impacts of climate change, uncertainty in the production of production, risk of significant negative effects on the environment.

Yambol agro region has a total arable land of 241,931 ha. The relief of a large part of the arable land is plane, and in separate parts of the municipalities Elhovo and Bolyarovo terrain is semi-mountainous. In the plane part there are different soil species, with a predominant soil type being Leached vertisols. In the semi-mountainous areas the soils are predominantly represented by Leached cinnamon forest soil. The soil fertility is largely determined by the organic substance humus, available food macro and micro elements, and the soil reaction. Table 3 reflects the content of humus, macro elements, and reaction of the soil for the two main prevailing soil types - leached vertisoil and leached cinnamon forest soil.

Table 3. Humus content, macro-elements nitrogen, phosphorus and potassium and soil reaction $(\mathrm{pH})$

\begin{tabular}{|c|c|c|}
\hline Content of: & Leached vertisoil $^{1}$ & Leached cinnamonic forest soil \\
\hline $\begin{array}{l}\text { Soil organic matter } \\
\text { (humus), \% }\end{array}$ & 3,2 & 2,2 \\
\hline Power humus horizon, $\mathrm{cm}$ & $50-80$ & $25-35$ \\
\hline $\begin{array}{l}\text { Nitrogen - nitrate }(\mathrm{N}) \\
\mathrm{mg} / \mathrm{kg}\end{array}$ & 13,33 & 0,09 \\
\hline Phosphorus $\left(\mathrm{P}_{2} \mathrm{O}_{5}\right), \mathrm{mg} / \mathrm{kg}$ & 2,3 & 1,8 \\
\hline Potassium $\left(\mathrm{K}_{2} \mathrm{O}\right), \mathrm{mg} / \mathrm{kg}$ & 49,80 & 41 \\
\hline Soil reaction (in $\mathrm{KCl}$ ) & 5,7 & 4,5 \\
\hline
\end{tabular}

According to data from laboratory analysis under project 2 FTT 14

${ }^{2}$ According to the Laboratory Analysis under the Agro Ecological Project "Development of Agricultural Activities for the Protection of the Environment" contract № 2006 - 070 POG between UNDP and Institute of Soil Science „N. Pushkarov“, Sofia

The land, which $31 \%$ of the organic farmers in Yambol Agro region use, is own agricultural land. $52 \%$ of the land used is rented land. The share of farmers bio-producer using own and rented land is the smallest - 17\% (Figure1), [9] [10]. Favorable of these data is that $1 / 3$ of the land is used own. This is largely a reason for farmers to conscientiously and responsibly take care of maintaining soil fertility.

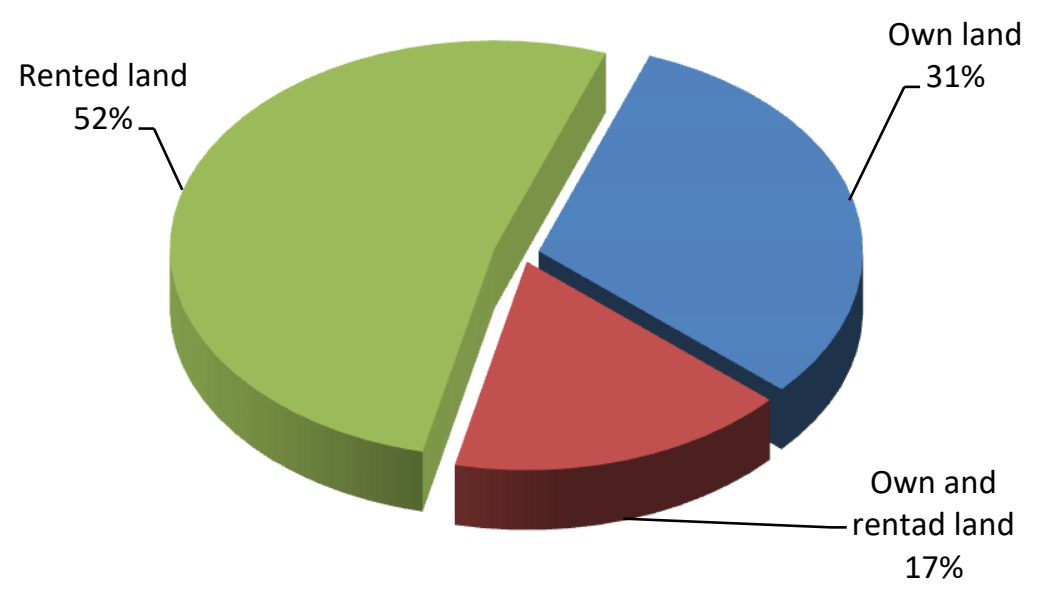

Figure 1. Percentage distribution of utilized agricultural land by organic producers in Yambol Agro region

IRTIIE Vol. 6, No. 4, 2018 ISSN 1314-8788 (print), ISSN 1314-8796 (online), doi: 10.15547/artte.2018.04.001 


\section{ARTTIE $Y$}

Ipplied Resseirlches in Teednicis, Technologies and Eductation

Journal of the Faculty of Technics and Technologies, Trakia University https://sites.google.com/a/trakia-uni.bg/artte/

Given the soil and climatic conditions of Yambol Agro region, bio-producers, depending on the cultivation of crops , are directed to the most appropriate measures for preserving the soil fertility according to their applicability. It can be seen from Figure 2 that the method of fertilization with organic fertilizers is the most widely used method (as outlined in Table 1). Widespread application have the crop rotation and sequential sequencing of soil treatments. Much of the agricultural bio-farmers use a combination of these methods, while respecting the soil cultivation sequence, properly formulated and adapted to the conditions of crop rotation and fertilization with organic fertilizers. Fertilizing with solid manure, which in the past has been widely used, is nowadays less using for bio-fertilizing. Understandably, bioproducers prefer bio-fertilizer on the one hand because of the ease of use and the wide variety of bio-based products on the market, and on the other hand due to the difficult supply of ecologically clean manure.

For increasing soil fertility an increasingly preferred method by organic farmers in the Yambol Agroregion is green fertilization (sideretion). Some of them, have prejudices and uncertainties about the merits of this method. Those actually applied include crops for green fertilization in the of crop rotation.

Unlike other the European countries, the use of compost and liquid manure is at least applied. The reason is that they do not have enough quantities available in the Yambol region and their demand and supply make it difficult for the agricultural bio-producers.

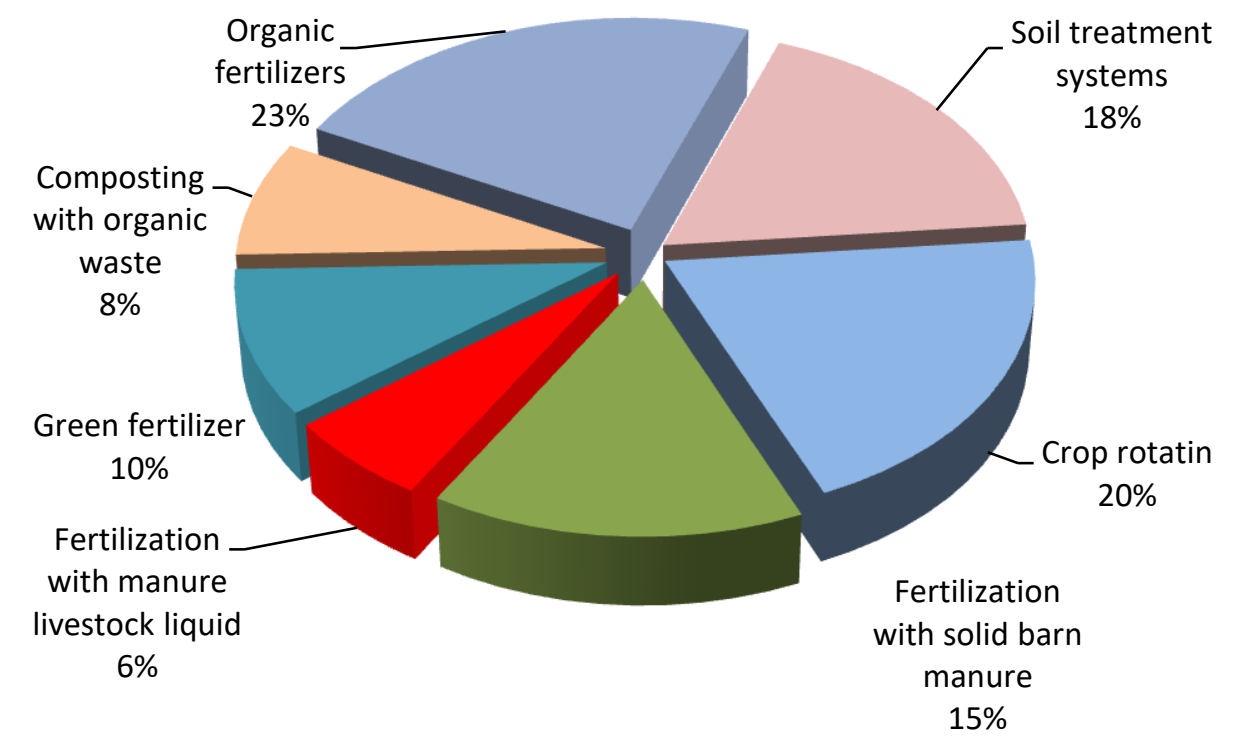

Figure 2. Percentage distribution of applied methods for preservation and restoration of soil fertility by the organic producers in Yambol Agro Region

\section{CONCLUSIONS}

As a result of the observations and analysis of the activities of the agricultural bio producers for maintenance and restoration of the soil fertility in Yambol region, the following more important conclusions can be made:

1. The predominant type of soils in the Yambol Agro region leached vertisols and leached cinnamon forest soils have relatively good potential soil fertility. It is necessary to take measures to protect and maintain it. 
2. The preservation and maintenance of the soil fertility in the agricultural lands of Yambol Agro Region is a conscious and priority policy of the farmers. Although, there are no systems for observing soil fertility status in arable land, agricultural bio-producers have implementing various measures for your preservation and preservation.

3. One third of the organic producers in the Yambol agrarian region use their own agricultural land. This largely determines the concern and implementation of measures to preserve soil fertility.

4. Organic farmers in Yambol Agroregion implement complex measures to preserve soil fertility, mainly targeting the use of bio-fertilizers, proper crop rotation and successive soil treatment systems.

\section{ACKNOWLEDGMENTS}

These studies were carried out in the frame of research project 2.FTT/ 2014 "Environmental Protection through Technological Solutions for Organic Agriculture in the Yambol Region" of the Faculty of Technique and Technologies of Yambol, Trakia University of Stara Zagora, Bulgaria.

\section{REFERENCES}

[1] Atanasov, A., Popov, R., Stankov, I., Grekov, D., Zhelyazkov, G. (2013). National Strategy for Sustainable Development of Agriculture in Bulgaria in 2014-2020.

[2] Mondeshka, M. (2006). Inventory of Soil Degradation Processes and Sustainable Land Management (SLM) in Bulgaria.

[3] Canazirska, N. Management of Soil Fertility in Organic Farming. New Knowledge, 25-35. ISSN: 13145703.

[4] Karov, S. Soil fertility main care in organic farming. CD version. aezecofarm.zona.bg/.../03. Soil fertility.

[5] Nankova, M. (2015). Soil organic matter - a function of crop rotation, processing and mineral fertilization. Soil Science, Agrochemistry and Ecology, Year XLIX, No 3, 67-83.

[6] Popov, VI. (2006). Basic Principles and Methods of Organic Agriculture, Agricultural University of Plovdiv, Agro-ecological Center.

[7] Goslinga, P., Shepherd, M. (2005). Longterm changes in soil fertility in organic arable farming systems in England, with particular reference to phosphorus and potassium. Agriculture, Ecosystems \& Environment, Vol.105, Issues 1-2, January 2005, 425-432.

[8] Lampkin, N., Measures, M. \& Padel, S., eds. (2002). 2002/03 Organic farm management handbook. Aberystwyth, Ceredigion, Wales, University of Wales, Institute of Rural Studies, Organic Farming Research Unite. ISSN 1354-3768. ISBN 1872064353.

[9] Legzdina, L., Skrabule, I. (2005). Plant breeding for organic farming: current status and problems in Europe., Seminar ENVIRFOOD, www.ecopb.org/09/envirfood_ organicplantbreeding.pdf.

[10] Scialbba, N., Hattam, C. (2002). Organic Agriculture, Environment and Food Security, Environment and Natural Resources Series, 4. Rome, Italy: Food and Agriculture Organization (FAO) of the United Nations.

[11] Vateva, V., Trendafilov. Kr. (2016). Aspects of organic farming in Yambol region status, opportunities and prospects. Innovation and Entrepreneurship. Scientific-Applied Journal, Volume IV, Number 3, 38-54. (Bg)

[12] Yancheva Chr., Manolov, I. et al. (2011). Organic farming. http://www.organic.aber.ac.uk/. 


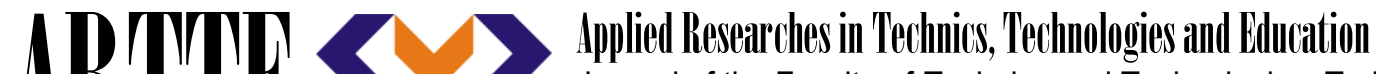 Journal of the Faculty of Technics and Technologies, Trakia University https://sites.google.com/a/trakia-uni.bg/artte/}

[13] National Report on the Status on Environment in the Republic of Bulgaria. Executive Environment Agency.http://www.eea.government.bg/bg/soer/2012.

[14] http://www.eea.government.bg/bg/soer/2015/land-use/sastoyanie-na-pochvite.

[15] http://www.dfz.bg/bg/kontakti/oblastni-strukturi/Yambol/.

[16] http://www.ODZG_Yambol@mzh.government.bg.

[17] www.naas.government.bg/bg/Библиотека/.../Почвено_плодородие. 